\title{
General Guidelines for Environmental and Technological Expertise of the Best Available Technologies Implementation at Large Industrial Enterprises in Russia
}

\author{
Alexander Zakondyrin ${ }^{1}$ \\ ${ }^{1}$ Association of Developers of Environmental Technologies and Environmental Initiatives, General \\ Director, 115054, 3rd Monetchikovsky per., 11/1, 501, Moscow, Russia
}

\begin{abstract}
In 2019, the National Ecology Project was launched in Russia, which is aimed at the efficient management of production and consumption waste, including the elimination of all unauthorized landfills identified on January 1, 2018 within the boundaries of cities, dramatic decrease in atmospheric air pollution in large industrial centers, including a reduction of at least 20 percent of the total volume of pollutant emissions into the air in the most polluted cities, improving the quality of drinking water for the population, especially residents of settlements. As the main task in the implementation of the Clean Air federal project, it is planned to implement comprehensive action plans to reduce emissions of pollutants into the air in large industrial centers, taking into account summary calculations of the negative environmental impacts allowed in these cities.
\end{abstract}

\section{Introduction}

The priority areas of state policy and strategic planning of the Russian Federation dictate the need to form a high-tech industry in the country, increase its competitiveness, ensure an innovative type of economic development while reducing the negative impact on the environment [1-2].

These tasks are supposed to be realized through the creation of effective mechanisms for the enforcement of policies in the fields of industry, environmental protection and management, energy conservation and energy efficiency, as well as through the coordinated interaction of participants in the process of economic relations regulating [3], [4], [5].

The goal of the implementation of the Best Available Technologies (BAT) federal project is to drastically reduce atmospheric air pollution in large industrial centers, including reducing by at least 20 percent the total amount of pollutant emissions into the air in the most polluted cities [6].

Achievement of the goal is carried out through the use of all facilities that make negative environmental impact (NEI), environmental management system based on the use of BAT. 


\section{Mechanisms of public control over the implementation of the best available technologies at industrial enterprises in Russia}

In accordance with Art. 31.1 of the Federal Law of January 10, 2002 No. 7-FZ "On Environmental Protection", [3] legal entities and individual entrepreneurs engaged in economic and (or) other activities at facilities of category I are required to obtain a comprehensive environmental permit (CEP), thereby confirming the introduction of BAT in production.

If it is impossible to obtain CEP by legal entities or individual entrepreneurs engaged in economic and (or) other activities at the facilities of category I, without fail in accordance with Art. 67.1 of the Federal Law of January 10, 2002 No. 7-FZ "On Environmental Protection" [3], a program for improving environmental performance (IEP) is being developed, which includes measures for the reconstruction, technical re-equipment of facilities that have a negative impact on the environment, the terms of its implementation, the amount and sources of financing, the list of officials responsible for their implementation [10].

According to Article 18 of the Federal Law of July 21, 2014 No. 212-FZ "On the Basics of Public Control in the Russian Federation" [8], public control is carried out in the forms of public monitoring, public inspection, public examination, in other forms that do not contradict this Federal Law, as well as in such forms of interaction of civil society institutions with state bodies and local authorities, such as public discussions, public hearings and other forms of interaction.

During the organization and conduct of public inspection, the subject of public control in accordance with Art. 20 of the Federal Law of July 21, 2014 No. 212-FZ "On the Basics of Public Control in the Russian Federation" [8] can collect and analyze information, verify the facts of the implementation of the BAT implementation program at the NEI site, including through environmental and technological assessment.

The main goal of the development of the state standard is to ensure uniform requirements for the public inspection procedure for an expert environmental and technological assessment of the introduction of BAT at the enterprise - the object of NEI.

The organizing and conduct of public audits for expert environmental and technological assessment of the introduction of BAT can be planned as well as unscheduled. A planned public audit of the introduction of BAT is carried out based on a plan for conducting public audits of the introduction of BAT, which, as a rule, is approved by the initiator of public audits of the introduction of BAT. An unscheduled public audit of the introduction of BAT can be appointed as the initiator of public audits of the introduction of BAT based on the results of the analysis of information on the activities of the facility providing the NEI obtained from open sources (interviews, briefings, press documents, business papers and archives), or unnamed (complaints) of information conferences, press releases, media reports, press services, news agencies), closed (official). An unscheduled public audit of the introduction of BAT is appointed in the event that violations have been identified in the activities of the facility providing the NEI.

The initiator of public audits of the introduction of BAT is developing and approving a plan for conducting public audits of the introduction of BAT for the year, devided by quarters. The specific time period for conducting a public audit of the introduction of BAT within the planned month is determined in conjunction with the object of a public audit of the introduction of BAT.

The organization and conduct of a public audit of the introduction of BAT includes the following steps:

- decision-making on conducting a public audit of the introduction of BAT;

- development and approval of a program of public review of the introduction of BAT; 
- the formation of a commission for public verification of the introduction of BAT;

- conducting a public audit of the introduction of BAT;

- reporting the results of a public audit of the introduction of BAT;

- informing on the results of a public audit of the introduction of BAT.

The time period for conducting a public audit of the introduction of BAT should not exceed thirty days.

The initiator of the public audit of the introduction of BAT makes a decision on its implementation. The decision is communicated (sending the appropriate letter) to the head of the inspected object of the public audit of the introduction of BAT.

Together with the decision, the head of the inspected object of the public audit of the introduction of BAT sends for approval the program of the public audit of the introduction of BAT containing the following information:

- the basis for conducting a public audit of the introduction of BAT;

- prospective members of the commission for public verification of the introduction of BAT (with justification for the involvement of experts);

- the timing of a public audit of the introduction of BAT;

- the procedure for conducting a public audit of the introduction of BAT and determining the results.

Before conducting a specific public audit of the introduction of BAT, it is necessary to specify the program of public inspection of the introduction of BAT. To this end, the initiator of the public audit of the introduction of BAT is requesting (sending a corresponding letter) from the object of the public audit of the introduction of BAT the documents and other materials necessary for conducting a public audit of the introduction of BAT. The commission for the public review of the introduction of BAT consists of the public experts or other persons of the subject of public control, as well as experts for environmental and technological assessment of the introduction of BAT (in case of absence of a conflict of interest in the implementation of public control).

A public audit of the introduction of BAT is carried out at the actual location of the object of the public audit of the introduction of BAT in the presence of representatives of the executive body of the object of the public audit of the introduction of BAT, as well as (if necessary) with relevant representatives of the audited enterprise.

Based on the results of a public audit of the introduction of BAT, a final document (Act) is prepared, which should contain:

- the grounds for conducting a public audit of the introduction of BAT;

- a list of documents and other materials studied during a public audit of the introduction of BAT;

- expert environmental and technological assessment of the introduction of BAT at the enterprise - the object of NEI;

- conclusions on the results of a public audit of the introduction of BAT and suggestions and recommendations for eliminating the identified violations.

The final document (Act), prepared according to the results of a public audit of the introduction of BAT, is placed by the subjects of public control in the Internet. At the same time, depersonalization of personal data is mandatory, including in relation to biometric personal data, special categories of personal data of a citizen in accordance with the Federal Law of the Russian Federation of July 27, 2006 No. 152-FZ “On Personal data. " [11].

If necessary, the subject of public control prepares a public presentation of the final results of a public audit of the introduction of BAT. Access to information based on the results of a public audit of the introduction of BAT, with the exception of results containing information constituting a state secret, information about personal data, and information access to which is restricted by federal laws, is open [12]. 


\section{Expert environmental and technological assessment of the introduction of BAT}

The subject of expert environmental and technological assessment of BAT implementation are technological processes, equipment, technical methods and methods used in carrying out economic and (or) other activities at the facility that have a negative impact on the environment, which is assigned category I when it is registered with the state facilities making NEI [9].

The subject of evaluation on a voluntary basis may also be technological processes, equipment, technical methods used in carrying out economic and (or) other activities at an object that has a negative impact on the environment, which is assigned category II when it is registered with the state, making NEI in accordance with the Federal Law of the Russian Federation of July 27, 2006 No. 149-FZ “On Information, Information Technologies and Information Protection" [9].

The process of expert environmental and technological assessment of the introduction of BAT consists of several stages. Evaluation of information on which areas of application of BAT include technological processes, equipment, technical methods and methods used at the object of public verification of BAT implementation. Assessment of the selection of measures for the introduction of BAT at the object of public verification of the introduction of BAT:

- assessment of the selected category I facility that provides NEI, solutions, techniques, methods, etc., referred to BAT for the respective areas of BAT application;

- evaluation of other solutions, including promising technologies selected by NEI of category I to achieve the targets (corresponding to industry technological indicators of BAT or the best indicators);

Analysis of the adequacy of measures for the implementation of public testing of BAT introduction of technological processes, equipment, technical methods, including:

- analysis of the results of comparing technological indicators that characterize each of the technologies used at the facility providing NEI, the technology with BAT indicators described in the relevant BAT, presented by an object of category I NEI;

- analysis of the results of a comparison of technological indicators presented by an object of category I providing an NEI, characterizing each of the technology used at the object providing an NEI, with BAT indicators approved by orders of the Ministry of Natural Resources and Ecology of the Russian Federation or a resolution of the Government of the Russian Federation (for organizations operating centralized drainage systems of settlements or urban districts).

\section{Conclusion}

An assessment of the need to improve the technological indicators achieved by the object of public verification of the introduction of BAT to ensure the implementation of industryspecific BAT indicators. If necessary, at the object of public inspection of the introduction of BAT, an assessment of economic information on the introduction of BAT are carried out.

\section{References}

1. Federal Law of the Russian Federation dated June 28, 2014 No. 172-FZ "On Strategic Planning in the Russian Federation” (Russian Newspaper Pub., Moscow, 2014) 
2. Decree of the Government of the Russian Federation of April 15, 2014 No. 328 "On approval of the state program of the Russian Federation" (Russian Newspaper Pub., Moscow, 2014)

3. Federal Law of January 10, 2002 No. 7-FZ “On Environmental Protection” (Russian Newspaper Pub., Moscow, 2002)

4. Federal Law of the Russian Federation dated December 31, 2014 No. 488-FZ "On Industrial Policy in the Russian Federation" (Russian Newspaper Pub., Moscow, 2014)

5. Federal Law of the Russian Federation dated November 23, 2009 No. 261-FZ "On Energy Saving and on Improving Energy Efficiency and on Amending Certain Legislative Acts of the Russian Federation".

6. Decree of the President of the Russian Federation dated May 07, 2018 No. 204 "On national goals and strategic objectives of the development of the Russian Federation for the period until 2024" (Russian Newspaper Pub., Moscow, 2018)

7. The passport of the federal project "Implementation of the best available technologies" approved by the decision of the Presidium of the Presidential Council for Strategic Development and National Projects on December 24, 2018 (Russian Newspaper Pub., Moscow, 2018)

8. Federal Law of July 21, 2014 No. 212-FZ "On the Basics of Public Control in the Russian Federation” (Russian Newspaper Pub., Moscow, 2014)

9. Decree of the Government of the Russian Federation of September 28, 2015 No. 1029 "On approval of the criteria for classifying objects that have a negative impact on the environment, to objects of categories I, II, III and IV" (Russian Newspaper Pub., Moscow, 2015)

10. Order of the Ministry of Natural Resources of Russia dated December 17, 2018 No. 666 "On approval of the rules for developing a program to increase environmental efficiency" (Russian Newspaper Pub., Moscow, 2018)

11. Federal Law of the Russian Federation of July 27, 2006 No. 152-FZ "On Personal Data" (Russian Newspaper Pub., Moscow, 2006)

12. Federal Law of the Russian Federation of July 27, 2006 No. 149-FZ "On Information, Information Technologies and Information Protection” (Russian Newspaper Pub., Moscow, 2006) 